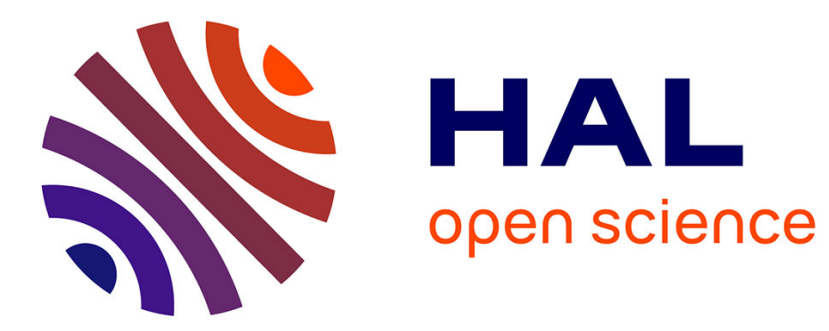

\title{
Ultrafast processes in metal clusters
}

\author{
L. Wöste
}

\section{To cite this version:}

L. Wöste. Ultrafast processes in metal clusters. Journal de Physique IV Proceedings, 1994, 04 (C4), pp.C4-711-C4-711. 10.1051/jp4:19944189 . jpa-00252649

\section{HAL Id: jpa-00252649 https://hal.science/jpa-00252649}

Submitted on 1 Jan 1994

HAL is a multi-disciplinary open access archive for the deposit and dissemination of scientific research documents, whether they are published or not. The documents may come from teaching and research institutions in France or abroad, or from public or private research centers.
L'archive ouverte pluridisciplinaire HAL, est destinée au dépôt et à la diffusion de documents scientifiques de niveau recherche, publiés ou non, émanant des établissements d'enseignement et de recherche français ou étrangers, des laboratoires publics ou privés. 


\section{Ultrafast processes in metal clusters}

\section{WÖSTE}

Freie Universität Berlin, Institut für Experimentalphysik, Amimallee 14, 1000 Berlin 33, Germany

Metal clusters exhibit extraordinary chemical and catalytical properties. These features arise from the fact that with the transition from the atom to the bulk the electronic and dynamic structure drastically changes. This causes significant alterations of the energetic behaviour of the clusters, going from single electronic transition lines to more and more complex features, finally leading to band structures. The pheriomenon is easily observable by means of laser spectroscopy. The spectroscopy of metal clusters on the other hand also exhibits the origin of the dynamical properties. In the case of alkalines for example, resonant two photon ionization is the best fitted method to obtain mass selective excitation spectra up to the trimer. Beyond that, however, no spectra were observed by this method. In the process of laser excitation larger particles tend to fragmentize. This is due to an increased amount of energetically very similar electronic states (bunching), and vibronic coupling. Only with the help of depletion spectroscopy spectra of these particles have become observable.

In quantum chemistry structure and electronic properties are commenly regarded as independent features. The symmetry of a system, however, has a drastic influence on the density of states. As a consequence the speed of fragmentation should increase with cluster size; except for cases, whenever a species of higher symmetry is examined. The observation of the phenomenon requires time-resolved spectroscopy. We applied transient two-photon-ionization spectroscopy in the pico- and femtosecond regime to alkaline clusters with a tunable delay between excitation and ionization (pump \& probe). As expected a wavepaket introduced into a dimer oszillates for ever $\left(<10^{-8}\right.$ $\mathrm{sec}$ ). The trimer alteady exhibits an attenuated oszillation about $5 \mathrm{psec}$. With growing cluster size ( $<\mathrm{Nag}$ ) this time continously decreases leading to ultrafast unimolecular decay. The data provide an insight into vibronic coupling, which constantly increases with state density. This phenomenon is of highest relevance for photochemical and catalytic applications. 